\title{
Celebrity endorsement and purchase intention: The case of Toyota Vios in Vietnam
}

\author{
Ha Minh Tri ${ }^{1 *}$ \\ ${ }^{1}$ School of Business, International University - Vietnam National University - HCMC, Vietnam \\ *Corresponding author: hmtri@hcmiu.edu.vn
}

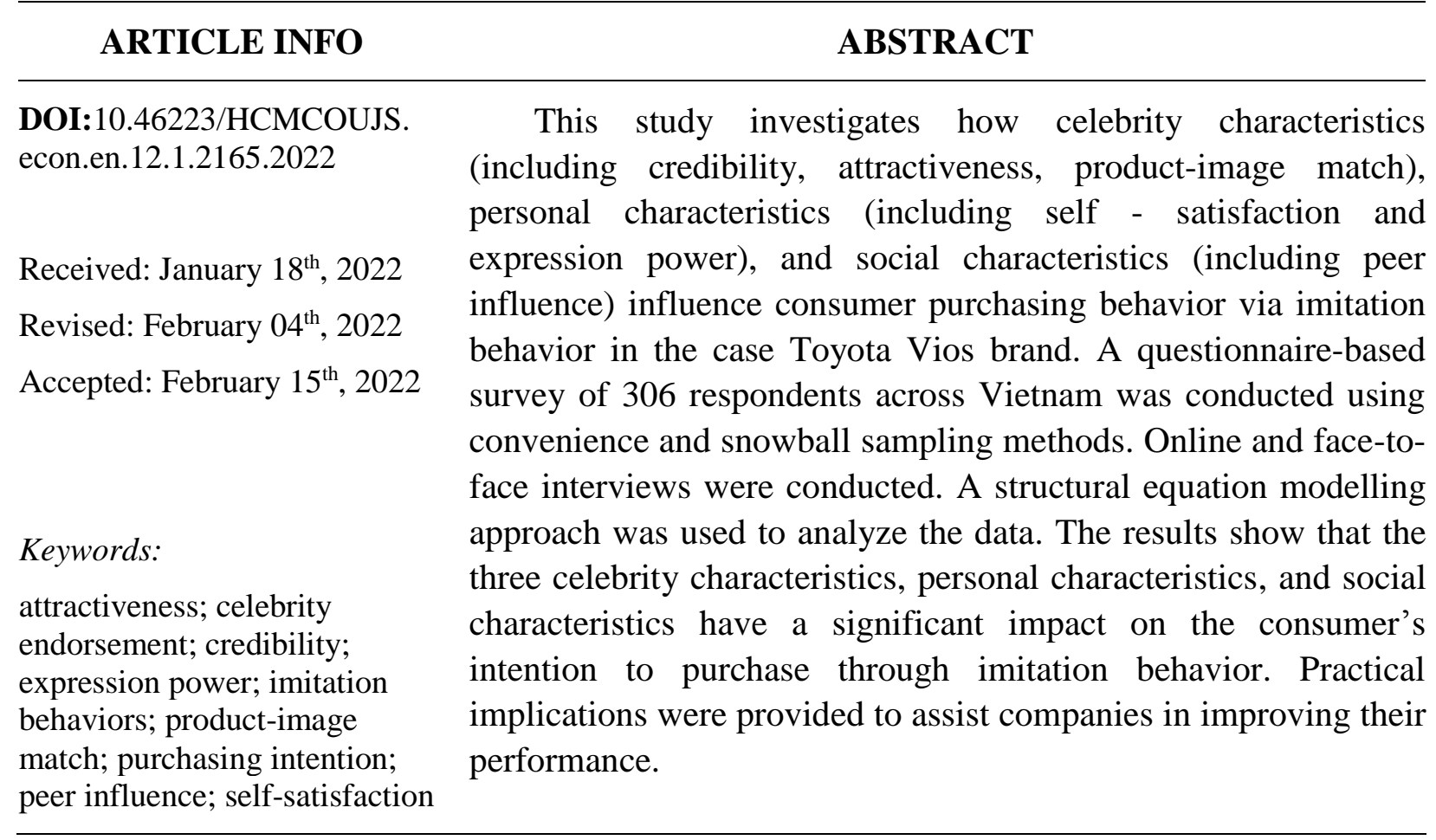

\section{Introduction}

In today's competitive market, the usage of a particular logo, emblem, and distinction to differentiate from certain products is all that the business attempts to create a brand (Armstrong, Adam, Denize, \& Kotler, 2014). In particular, when the company launches a product or service of good quality, this element is not an absolute determinant of the company's success in a competitive market (Kutthakaphan \& Chokesamritpol, 2013). Understanding potential customers and choosing the right communication tool for a company's products and services is one of the most critical factors a company must recognize (Armstrong et al., 2014). There are various means to promote the brand, and using celebrity endorsement is among the choices of marketing methods that help a brand grows (Friedman, Termini, \& Washington, 1976).

There has been an explosion of young musicians in the Vietnamese entertainment sector, with names such as Suboi, Issac, Khoi My, Vu Cat Tuong, Duc Phuc, and Erik appearing in advertising used by the corporation to market its brand since it began to grow in 2015 in Vietnam (Nguyen, 2017). In addition, some companies invite celebrities to represent the company's brand in many different products, such as cars, smartphones, cosmetics, and food. McCracken (1989) contended that with the relevance of celebrities, attractiveness, dynamic image, and brands combined with certain groups of fans and public awareness, the artist is expected to attract the attention of the audience while creating a positive attitude for the several products that lead to 
imitations and consumer buying intent. As a result, Toyota Vios - a class of mid-range automobiles combining Thailand and Japan - selects celebrities to promote the brand, as do many other manufacturers. Toyota Vios has been on the market in Vietnam since 2003, and it has quickly become a sensation that is well-liked by consumers and chosen by many customers in the struggle for market share.

In fact, looking through the lenses of commercial benefits, advertising by celebrities boost customer awareness of the brand while also giving chances to expand the brand and increase revenue for the company as well as expand consumer group (Freire, Quevedo-Silva, Senise, \& Scrivano, 2018; Lafferty \& Goldsmith, 1999). Once again, in 2018, the company stepped up its branding campaign to create a deep impression as well as increase brand recognition from customers when Toyota Vios released a new generation of breakthrough automobiles with a motto "No Quality - No Life". In particular, the company officially introduced the short film "Valueadded service chain" about Toyota Vios with the participation of the main actor, the music artist Rap Suboi - and also the brand ambassador of Toyota in Vietnam on the entertainment channel. Suboi has been dubbed the "Queen of Vietnam hip-hop music" by many foreign publications. She is also recognized for the image of a girl rap personality in front of US President Barack Obama, which has garnered worldwide attention (Thanh Huong, 2017). The rapper's achievements are all the first-time Vietnamese artists achieved on the international market, the "boom" that others have to respect. In March 2015, Suboi surpassed more than 15,000 other candidates, becoming one of the artists participating in the world's largest music festival SXSW (South by Southwest) in the United States. In the advertising field, Suboi is involved in the promotion campaign of a global brand with ambassador status. Suboi and illustrious photographer Jean-Paul Goude made a set of photos for the H\&M x Kenzo brand. With such continuous success, therefore, Suboi is invited to be a brand spokesperson for Toyota Vios as part of their marketing plan (Thuy Lien, 2016).

At the same time, celebrities, as well as marketers, are under pressure to find the appeal and attention of consumers. The celebrity's promotion of products through traditional marketing methods such as distributing leaflets or mailing to customers leads to dissatisfaction from customers (Dima, Teodorescu, \& Gîfu, 2014). Therefore, the effectiveness of celebrity endorsers is not effective for a company's product. To overcome this situation, celebrities need to find specific modern communication methods such as promoting products through "Social Media" to attract as well as communicate with consumers (Dima et al., 2014). Moreover, according to previous studies, the impact of celebrity endorsement on customer transactions also allows the use of the celebrity's characteristics features, that is, attractiveness, expertise, and trustworthiness (Gauns, Pillai, Kamat, Chen, \& Chang, 2018). In fact, little has been done to integrate the influence of celebrity endorsement ads on consumer buying by way of a combination of three personality traits that are the core attributes of celebrities (credibility, product-image match, attractiveness), social characteristics (peer influence) and personal characteristics (self - satisfaction, expression of power) (Awasthi \& Choraria, 2015; Choi \& Rifon, 2012; Kutthakaphan \& Chokesamritpol, 2013). Thus, our study wants to bridge this research gap. More specifically, the objectives of our study are to identify and evaluate the effects of celebrity endorsements on purchase intention via imitation behavior of Toyota Vios's customers.

\section{Literature review and hypotheses development}

\subsection{Background theories}

Our work relies on theories of Meaning transfer theory (McCracken, 1989) and Social Learning Theory (Bandura, 2006) when analyzing the impact of ads that endorses celebrities on customer sales of current goods. 


\subsubsection{Social learning theory}

The theory of social learning is commonly employed in several businesses in the media and product ads industries (Bandura, 2006). It is based on social actors that predict consumer behavior (Kitayama \& Uskul, 2011). Social actors support individuals to achieve inspiration and demonstrate positive behaviors through overt or indirect contact (Manz \& Sims, 1980). The theory of social learning may describe the effect on customer habits from celebrities, who are deemed endorsers by third parties (Rosenstock, Strecher, \& Becker, 1988). It has a significant effect as third-party endorsers need to understand how to talk and behave; for example, a celebrity needs to recognize which items to use to manipulate people. Celebrity factors such as charisma and reliability can make people ready to imitate them (Awasthi \& Choraria, 2015). Therefore, the social theory explains that celebrity endorsements in advertising affect consumers' intentions because they watch, listen, observe, and want to use products that celebrities choose (Roozen \& Claeys, 2010).

\subsubsection{Meaning transfer theory}

According to McCracken (1989), if being done correctly, a celebrity will turn a common collection of definitions into the advertised product. There are three phases to discuss in this theory, namely culture, endorsement, and consumption.

\subsubsection{Culture}

The idea of this theory is that celebrities are used more in advertising than anonymous models because celebrities are seen as inspiration and power to viewers. So, the problem is why celebrities are being used in ads, what impact does a celebrity has on the advertisement, brands, and customers, and how celebrities have so much interest in adding significance to the process (McCracken, 1989).

\subsubsection{Endorsement}

One branch of the theory is that choosing a celebrity depends on the context and publicity campaign they represent (Schimmelpfennig, 2018). In particular, the campaign is represented in four different stages, from deciding symbolic qualities budget to selecting the most suitable celebrity and designing a complete campaign. Therefore, the advertisement often has to demonstrate the parallels between brands and celebrities to encourage customers to embrace the message (Schimmelpfennig, 2018).

\subsubsection{Consumption}

The sense of going from producer to customer, because celebrities play an important role by establishing themselves at the end of the cycle of sense transition, makes celebrities the most important factor in this period (McCracken, 1989). Celebrities who build themselves are always attractive and successful to be consumers who inspire consumers and, at the same time, get admiration from consumers (Kutthakaphan \& Chokesamritpol, 2013). Therefore, celebrities can provide some meaning to consumers because when celebrities are involved in the authentication process, consumers are given the same meaning by celebrities available in material form. In addition, celebrities are considered key figures because they have created strong, clear, and coherent personalities that everyone is looking for (Kutthakaphan \& Chokesamritpol, 2013).

\subsection{Celebrity endorsement}

People who are recognized and able to influence individuals in society are called celebrities (Lee \& Thorson, 2008). Celebrities also have unique qualities, including attractiveness, lavish 
lifestyle, and special skills (Amos, Holmes, \& Strutton, 2008). Celebrities have widespread popularity and appearance in public events, television, newspapers, fashion shows, and particularly advertisements (Eisend \& Langner, 2010). A celebrity promoting a firm's product has become highly common, implying instant awareness of the brand (Till \& Busler, 1998).

\subsection{Dimensions of celebrity characteristics}

\subsubsection{Credibility of celebrity characteristics}

To what degree an individual sees the source with appropriate qualifications, expertise, or experience is called trustworthy (Stacks, 2019). That means the degree to which the person trusts the source in providing accurate and unbiased information. Expertise and credibility are two significant reputational factors. Expertise is described as a celebrity's cognitive capacity to render a legitimate application (Hani, Marwan, \& Andre, 2018). Ad acceptance depends on the credibility of celebrities and the ability of people to rate the product. A source must be trustworthy and ethical in order to be considered persuasive (Elleström, 2018). In fact, by an internalization process, specialists and reputable outlets become more credible and more dominant on values, views, behaviors. This cycle of localization occurs as customers embrace celebrity opinions. After that, the idea-collection should be incorporated into the customer trust network and held forever. A credible source is critical when public sentiment is negative about the product/brand (Belch \& Belch, 2004). Thus, we formulate a hypothesis as follows.

\section{H1: Credibility affects customer's imitation behavior positively}

\subsubsection{Attractiveness of celebrity characteristics}

The principle of source attraction indicates that the reception of the message is based on the celebrity's uniqueness, skill, and familiarity. The connection between a celebrity and the public, the willingness to be affectionate with the celebrity's behavior, and presence via empathy is the celebrity's awareness by contact (Kim \& Na, 2007). Identity occurs when the target audience is defined themselves with celebrities and tends to accept celebrity attitudes, beliefs, habits, and opinions. In this case, the brand is considered to have inherited the celebrity's attraction when the celebrity has established a feeling of stability with the brand. Some celebrities draw attention to ads but not products or brands. An attractive celebrity is believed to promote brand identification but does not increase message retrieval. Advertisers must ensure that advertising messages attract the attention of consumers (Reid \& Soley, 1983). Thus, we have a hypothesis as below.

\section{H2: Attractiveness affects customer's imitation behavior positively}

\subsubsection{Product-image match of celebrity characteristics}

The persuasion of a celebrity endorsement is described as a feature of how the picture of the endorsement suits the product the celebrity is displaying (Homer \& Kahle, 1988). The relevance of celebrities and products is thought to be a key component in deciding the influence of celebrity endorsement (Knoll \& Matthes, 2017). Specifically, previous studies indicate that the influence in a physical appeal is reciprocal and conclude that celebrity endorsing is more successful than unattractive desirable spokeswoman items (e.g., perfumes, cosmetics, and hair care goods) (Choi \& Rifon, 2012). Conversely, practical, technology-related goods may not produce this sort of effect owing to the irrelevance of commodity style attractiveness (Till \& Busler, 2000). Hence the level of trustworthiness and efficacy required for the brand is the consequence of the maximum relevance to the lowest relevance between the celebrity's public identity and the company (Kamins \& Gupta, 1994; Roth \& Romeo, 1992). Hence, a hypothesis was formed below. 


\section{H3: Product-image match affects customer's imitation behavior positively}

\subsection{Personal characteristics}

Personal characteristics are features specific to one individual and may not involve other people in the same group (Baldry \& Farrington, 2000). Such characteristics include the manner in which an individual (i.e., a consumer) creates particular tastes and behaviors and the judgment and decision of a customer on buying a commodity. Decisions when assessing particular considerations can be affected by popular image, celebrity, or spectator (Koustelios, 2001). Consumers are looking for products that fulfill their basic needs and desires. The actions of customers are far greater than what the buyers pay (Cross \& Dixit, 2005). It seeks to explain how the decision-making cycle takes place and how it impacts the actions of customers. Therefore, consumers purchasing a particular commodity are also not easy to negotiate with since the solution is trapped in the head of the buyer.

\subsection{Dimensions of personal characteristics}

\subsubsection{Self - satisfaction of personal characteristics}

In the case of celebrity endorsements, consumers are pleased with the photos of a celebrity being passed by when purchasing products or services and the attention they earn (Awasthi \& Choraria, 2015). Individuals, practices, and organizations are less important than selves (Baumeister, 1991). It is the person responsible for the formation of definitions; in particular, the entity carries out the function of constructing a coherent structure, utilizing all sorts of cultural elements and at the same time trying to conform human factors to cultural factors (Theodorakis, Malliou, Papaioannou, Beneca, \& Filactakidou, 1996). Hence the main aim is to align one-self's subjective influences with the empirical elements of culture. The belief that individuals should mimic celebrities' conduct makes them happy and is easy to obey and accept by others (Awasthi $\&$ Choraria, 2015). Self - satisfaction is used to assess the position of imitation that the behavior performs. Therefore, it is reasonable to formulate a hypothesis below.

\section{H4: Self - satisfaction affects customer's imitation behavior positively}

\subsubsection{Expression of power of personal characteristics}

In interpersonal relationships, power is defined as an asymmetry (e.g., asymmetry in knowledge or dependence) (Nelson \& Aboud, 1985; Simon, 1953). Asymmetry in partnerships usually comes from the capacity to possess wealth, such as the right to contest or control an unchangeable object, such as photographs and information (Noë, van Schaik, \& van Hooff, 1991; Smith \& Parker, 1976). One may mimic acquiring any information or intelligence and projecting it to manifest a superior force and surrounding resources. Besides, power is a more general term as it encompasses both supremacy and influence, whereas supremacy is stated as strengthdependent or force-threatening (Nye, 1990). Therefore, customers often imitate celebrity behaviors to prove themselves as powerful people; this element is called expression of power. Hence, we form a hypothesis as below.

\section{H5: Expression of power affects customer's imitation behavior positively}

\subsection{Social characteristics}

Social influences have an enormous impact on customer behavior. The growing person has someone around who affects their decision to purchase. Essential social influences are a community, relatives, position, and level of comparison (Perreault, 2014). Each customer is a person but is still part of a collective. The group, the consumer, belongs to is called the membership group (Perreault, 2014). 


\subsection{Dimensions of social characteristics}

\section{Peer influence of Social Characteristics}

Peer influence is a trend in which an individual appears to be affected by a peer's way of living and thought (Piehler, 2011). It contributes to a condition where there is an acceptable mindset in a community. Effective peer mediation requires knowledge of the connection between each other's emotions, attitudes, and needs (Stafford, 2004). Effective peer influence involves an awareness of the connection between the emotions, behavior, and needs of each other (Stafford, 2004). People that are more geared towards social interaction indicate a tendency to agree with other "wishes" and the ability to embrace and benefit from others. The first is the standard influence, and the other is the impact of knowledge. This also means that the individual wants to boost his appearance by literature on assets (Bearden, Netemeyer, \& Teel, 1989). For example, when a customer who is greatly affected by the group is impressed (i.e., celebrity) selectively and through their actions, it may affect customers directly or indirectly through the actions of celebrities. Thus, we formulate a hypothesis as follows.

\section{H6: Peer influence affects customer's imitation behavior positively}

\subsection{Imitation behavior}

Imitation is a learning mechanism that involves regulation over vision, awareness, expression, memory, and behavior (Meltzoff \& Moore, 1994). This method includes two separate forms of activities: examining what one learns and replicating it. The significance of the period or position where imitation is conducted, the various characteristics of the situation being practiced, the status of the person taking action, and the social experience were addressed (Nehaniv, Polani, Dautenhahn, Beokhorst, \& Cañamero, 2002). Imitation is an efficient means of understanding new functionality by building on the experience of others (Borenstein \& Ruppin, 2005). This is an effective means of moving information from instructor to viewers utilizing a specific context (Hoffman, Grimes, Shon, \& Rao, 2006). For the reasons mentioned above, consumers tend to imitate celebrity behaviors. Celebrities' behaviors will influence perception, which may promote understanding. It may also help consumers seek sense or attention.

\subsection{Purchase intention}

In choosing to purchase a brand or commodity, the decision to buy is decided by the consumers (Alam \& Sayuti, 2011). There are a number of factors involved in a buying intention, such as the purchaser's willingness to create a sale, potential spending desires, and a repurchase decision (Joshi \& Rahman, 2015). Furthermore, a range of steps are included in the decisionmaking cycle for buying and repurchasing such goods from customers. The customer decisionmaking mechanism is clarified into five systems that require accreditation, quest details, alternative assessment, purchasing intentions (Belch \& Belch, 2004). Therefore, the customer must complete all steps until they agree to buy a specific product.

\subsection{The relationship between customer's imitation behavior and purchase intention}

The purpose of the consumer to purchase is linked to the propensity to buy a specific brand or commodity (Belch \& Belch, 2004). The intention to purchase also indicates the likelihood of purchasing the product (Phelps \& Hoy, 1996). Imitation is a code of ethics with soft logic principles, and people select a behavior that is considered effective based on previous payments (Apesteguia, Huck, Oechssler, \& Weidenholzer, 2010). Amos et al. (2008) suggest that a positive imitation of a customer with a celebrity endorsement will improve his/her buying intent; for example, many studies have also shown that customer imitations of brands have a significant effect 
on purchase intent (Batra \& Ray, 1986; Phelps \& Hoy, 1996). Therefore, a hypothesis is formulated as follows.

\section{H7: Customer's imitation behavior affects customer's purchase intention positively}

Figure 1 depicts the research framework as presented below.

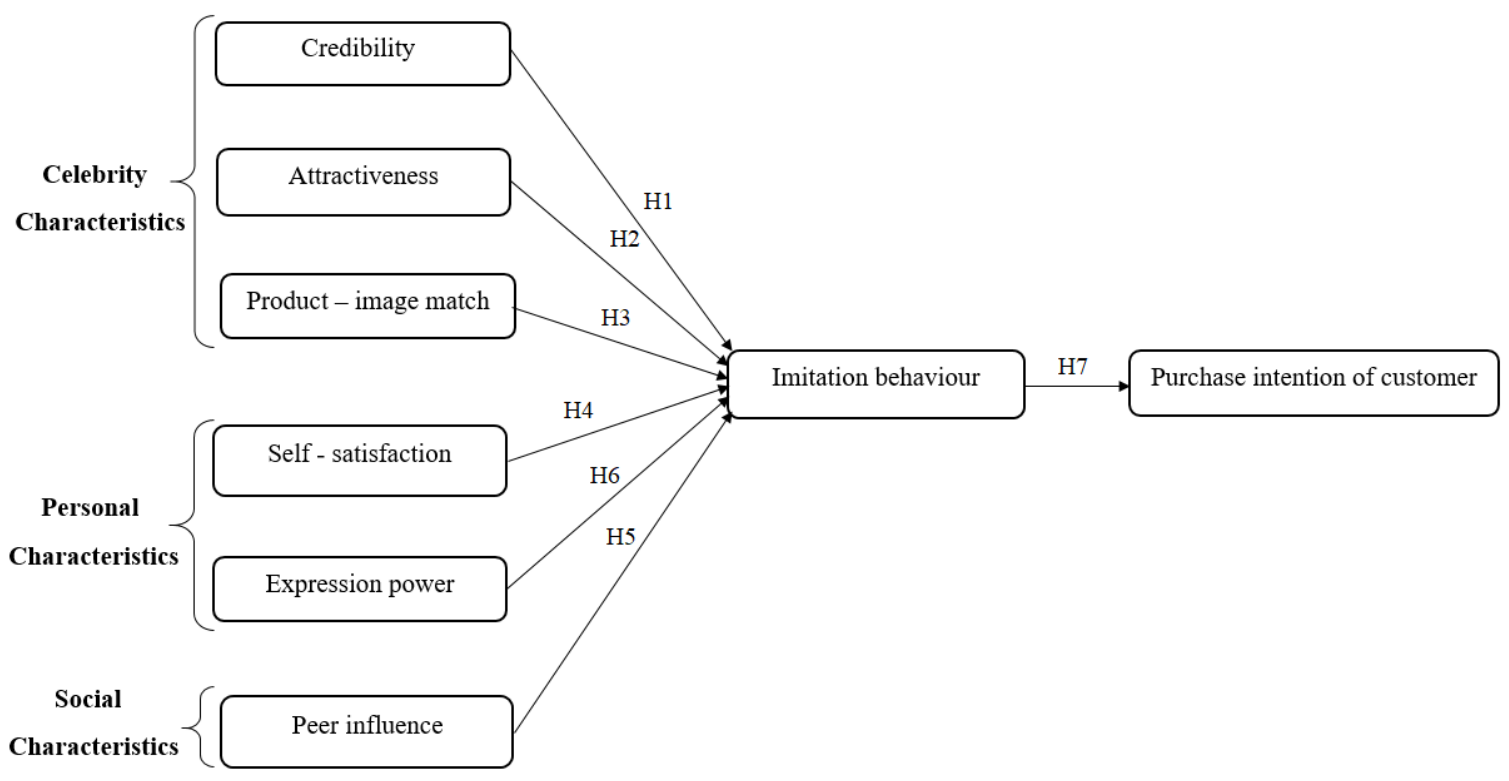

Figure 1. Research framework

\section{Methodology}

\subsection{Data collection and sampling}

We used a questionnaire-based survey for our study. The survey approach is time- and cost-effective. Respondents were of all ages and races who planned to purchase a Toyota Vios. Data was collected using a Google form through email and personal contacts. Our study used convenience and snowball sampling techniques. Prior to the collection of data, the questionnaire was pretested. The aim of the pretesting was to determine if there were any things that were challenging to address due to length of statement, anonymity, syntax or specific terms (Colton \& Covert, 2015). Pre-testing also helped to improve construct validity (Shadish, Cook, \& Campbell, 2002). We found certain terminologies difficult to understand by the respondents. We thus provided a short explanation for a better understanding of the terms. The questionnaire was then updated on the basis of the pretest results to enhance readability and understandability. A total of 349 contacts was reached and returned a total of 306 valid answers, accounting for an $87.7 \%$ response rate.

\subsection{Measurement scales}

Our study used a five-point Likert scale to measure all observed variables, ranging from " 1 " (strongly disagree) to " 5 " (strongly agree). The measurement scales were taken and adapted from prior literature. Specifically, credibility with four items, attractiveness of celebrity endorsers with three items, self-satisfaction with three items, expression of power with three items, peer influence with three items, imitation behavior with five items, purchase intention with three items were taken from Awasthi and Choraria (2015), and product-image match with three items was adapted from Kutthakaphan and Chokesamritpol (2013) and Choi and Rifon (2012). Table 1 presents the scales and other scale statistics. 


\section{Table 1}

Measurement Scale and responding measures

\begin{tabular}{|c|c|c|c|c|c|c|c|}
\hline Construct & Code & Description & $\begin{array}{l}\text { Factor loading } \\
\text { (FL) }\end{array}$ & SMC & $\alpha$ & $\mathbf{C R}$ & AVE \\
\hline \multirow[t]{4}{*}{ Credibility } & CRE1 & $\begin{array}{l}\text { The celebrity looks to be trustworthy in } \\
\text { the commercial. }\end{array}$ & $0.880 * * *$ & 0.527 & \multirow[t]{4}{*}{0.897} & \multirow{4}{*}{0.898} & \multirow{4}{*}{0.688} \\
\hline & CRE2 & $\begin{array}{l}\text { In the commercial, the performers } \\
\text { appear solemn. }\end{array}$ & $0.878 * * *$ & 0.681 & & & \\
\hline & CRE3 & $\begin{array}{l}\text { In the advertisement, the celebrity } \\
\text { shows are trustworthy. }\end{array}$ & $0.825 * * *$ & 0.771 & & & \\
\hline & CRE4 & $\begin{array}{l}\text { The celebrity who appears in the ad is } \\
\text { credible. }\end{array}$ & $0.726 * * *$ & 0.774 & & & \\
\hline \multirow[t]{3}{*}{$\begin{array}{l}\text { Product - } \\
\text { Image match }\end{array}$} & IMA1 & $\begin{array}{l}\text { I think that the celebrity endorser is the } \\
\text { right Toyota Vios representative. }\end{array}$ & $0.727 * * *$ & 0.529 & \multirow[t]{3}{*}{0.847} & \multirow{3}{*}{0.850} & \multirow{3}{*}{0.655} \\
\hline & IMA2 & $\begin{array}{l}\text { I immediately associated the celebrity } \\
\text { endorsement with the Toyota Vios } \\
\text { brand. }\end{array}$ & $0.849 * * *$ & 0.721 & & & \\
\hline & IMA3 & $\begin{array}{l}\text { Toyota Vios' brand celebrity identity is } \\
\text { congruent. }\end{array}$ & $0.845 * * *$ & 0.713 & & & \\
\hline \multirow[t]{3}{*}{$\begin{array}{l}\text { Self - } \\
\text { satisfaction }\end{array}$} & SAT1 & $\begin{array}{l}\text { The actress used in the commercial for } \\
\text { the Toyota Vios is attractive. }\end{array}$ & $0.749 * * *$ & 0.562 & \multirow[t]{3}{*}{0.839} & \multirow{3}{*}{0.840} & \multirow{3}{*}{0.636} \\
\hline & SAT2 & $\begin{array}{l}\text { The actor used in advertising Toyota } \\
\text { Vios appears elegant. }\end{array}$ & $0.820 * * *$ & 0.672 & & & \\
\hline & SAT3 & $\begin{array}{l}\text { I give more attention to the Toyota Vios } \\
\text { commercial portrayed by a } \\
\text { lovely/handsome actor. }\end{array}$ & $0.821 * * *$ & 0.674 & & & \\
\hline \multirow[t]{3}{*}{ Attractiveness } & ATT1 & $\begin{array}{l}\text { Celebrities encourage me to make } \\
\text { myself look good. }\end{array}$ & $0.808 * * *$ & 0.548 & \multirow[t]{3}{*}{0.824} & \multirow{3}{*}{0.830} & \multirow{3}{*}{0.619} \\
\hline & ATT2 & $\begin{array}{l}\text { When I follow the celebrities suggested } \\
\text { by others/celebrities, I feel happy. }\end{array}$ & $0.810^{* * *}$ & 0.657 & & & \\
\hline & ATT3 & $\begin{array}{l}\text { Celebrity-recommended products/ } \\
\text { services are worth purchasing. }\end{array}$ & $0.741 * * *$ & 0.653 & & & \\
\hline \multirow[t]{3}{*}{$\begin{array}{l}\text { Expression of } \\
\text { power }\end{array}$} & EXP1 & $\begin{array}{l}\text { To get what I want, sometimes I need to } \\
\text { use the valuable Toyota Vios brand to } \\
\text { fight against others. }\end{array}$ & $0.720 * * *$ & 0.636 & \multirow[t]{3}{*}{0.775} & \multirow{3}{*}{0.778} & \multirow{3}{*}{0.539} \\
\hline & EXP2 & $\begin{array}{l}\text { I believe that owning a Toyota Vios } \\
\text { product will dominate the inferior one. }\end{array}$ & $0.681 * * *$ & 0.463 & & & \\
\hline & EXP3 & $\begin{array}{l}\text { In order to progress in life, I } \\
\text { occasionally have to step on others by } \\
\text { purchasing Toyota Vios value } \\
\text { merchandise. }\end{array}$ & $0.797 * * *$ & 0.519 & & & \\
\hline \multirow[t]{3}{*}{$\begin{array}{l}\text { Peer } \\
\text { Influence }\end{array}$} & PEE1 & $\begin{array}{l}\text { Before I buy, I see what they are doing } \\
\text { and use my colleagues. }\end{array}$ & $0.719 * * *$ & 0.517 & \multirow[t]{3}{*}{0.784} & \multirow{3}{*}{0.787} & \multirow{3}{*}{0.555} \\
\hline & PEE2 & $\begin{array}{l}\text { My mates appreciate the products and } \\
\text { the labels I choose. }\end{array}$ & $0.669 * * *$ & 0.448 & & & \\
\hline & PEE3 & $\begin{array}{l}\text { I just purchase those things, and my } \\
\text { friends approve of such products. }\end{array}$ & $0.836^{* * *}$ & 0.699 & & & \\
\hline \multirow{2}{*}{$\begin{array}{l}\text { Imitation } \\
\text { behavior }\end{array}$} & IMI1 & I want to be just as skillful as film icons. & $0.861 * * *$ & 0.742 & \multirow[t]{2}{*}{0.915} & \multirow[b]{2}{*}{0.918} & \multirow[b]{2}{*}{0.692} \\
\hline & IMI2 & $\begin{array}{l}\text { I'm hoping to be as trendy as the } \\
\text { characters in commercials. }\end{array}$ & $0.862 * * *$ & 0.695 & & & \\
\hline
\end{tabular}




\begin{tabular}{|c|c|c|c|c|c|c|c|}
\hline Construct & Code & Description & $\begin{array}{c}\text { Factor loading } \\
\text { (FL) }\end{array}$ & SMC & $\alpha$ & $\mathbf{C R}$ & AVE \\
\hline & IMI3 & $\begin{array}{l}\text { I, like renowned personalities, simply } \\
\text { want to be fashionable. }\end{array}$ & $0.834 * * *$ & 0.5 & & & \\
\hline & IMI4 & $\begin{array}{l}\text { Even I have tried to change aspects of } \\
\text { my looks to resemble celebrities. }\end{array}$ & $0.882 * * *$ & 0.778 & & & \\
\hline & IMI5 & I adore and respect the celebrity. & $0.707 * * *$ & 0.743 & & & \\
\hline \multirow[t]{3}{*}{$\begin{array}{l}\text { Purchase } \\
\text { intention }\end{array}$} & PUR1 & $\begin{array}{l}\text { I certainly would purchase the } \\
\text { commodity that the celebrity endorses } \\
\text { in the ad. }\end{array}$ & $0.717 * * *$ & 0.514 & \multirow[t]{3}{*}{0.783} & \multirow{3}{*}{0.790} & \multirow{3}{*}{0.557} \\
\hline & PUR2 & $\begin{array}{l}\text { I can buy the things that the celebrity } \\
\text { promotes instead of the ones that aren't. }\end{array}$ & $0.786^{* * *}$ & 0.618 & & & \\
\hline & PUR3 & $\begin{array}{l}\text { The ads focused on celebrities } \\
\text { encourage me to buy a certain } \\
\text { commodity that has been endorsed. }\end{array}$ & $0.734 * * *$ & 0.539 & & & \\
\hline
\end{tabular}

Note: $* * *$ significant at $\mathrm{p}<.001$

Source: Author's calculation

\section{Research findings}

\subsection{Demographic analysis}

As observed in Table 1, the proportions of the two genders are approximately equal. As the graphic shows, the largest age demographic proportion belongs to the 18-25-year-old group with a rate of $43 \%$, followed by the group of 26-a 35-year-old group with $35 \%$. In addition, the majority of respondents reported themselves possessing a bachelor's degree (59\%). Regarding occupation, there are $20 \%$ of the participants hold managerial positions, and $44 \%$ of the respondents are office workers. The remaining is of students, freelancers, and officers.

\section{Table 2}

Participants' profile

\begin{tabular}{|l|l|l|l|}
\hline & & Number & Percentage \\
\hline \multirow{4}{*}{ Gender } & Male & 147 & $48 \%$ \\
\cline { 2 - 4 } & Female & 159 & $52 \%$ \\
\hline \multirow{4}{*}{ Age } & $18-25$ years old & 132 & $43 \%$ \\
\cline { 2 - 4 } & $26-35$ years old & 106 & $35 \%$ \\
\cline { 2 - 4 } & $36-45$ years old & 45 & $15 \%$ \\
\cline { 2 - 4 } & Over 45 years old & 23 & $8 \%$ \\
\hline \multirow{5}{*}{ Occupation } & High school & 89 & $29 \%$ \\
\cline { 2 - 4 } & College or university & 181 & $59 \%$ \\
\cline { 2 - 4 } & Graduate institute & 36 & $12 \%$ \\
\cline { 2 - 4 } & Otudent & 35 & $11 \%$ \\
\cline { 2 - 4 } & Officer & 136 & $44 \%$ \\
\cline { 2 - 4 } & Manager/Director & 60 & $20 \%$ \\
\hline & Freelancer & 75 & $25 \%$ \\
\hline
\end{tabular}

Source: Author's calculation 


\subsection{Measurement model assessment}

Table 1 presents the Factor Loadings (FL), Squared Multiple Correlation (SMC) of all measured variables, and the Critical Ratio (CR) and Average Variance Extracted (AVE) of all constructs in our measurement model. All FLs were significant at $p \leq .001$ as demonstrated in Table 1 (Anderson \& Gerbing, 1988), and were > .50 (Hair, Black, Babin, \& Anderson, 2019). All SMCs were well above the threshold value of .40 (Bollen, 1989). Following Nunnly and Bernstein (1994), all CRs, suggest that the measures are reliable and surpass the suggested values of .70. According to Fornell and Larcker (1981), all AVEs were > .50, implying that the measurement model achieved convergence validity.

In terms of discriminant validity, Table 3 shows that no violation can be found because each construct's square root of AVE was greater than the association between it and any other construct, implying discriminant validity (Fornell \& Larcker, 1981). Therefore, the measurement model of our study is acceptable in validity and reliability. Furthermore, the model fit statistics revealed that $\chi 2=399.059(\mathrm{df}=296, \mathrm{p}=.000), \mathrm{CMIN} / \mathrm{df}=1.348, \mathrm{SRMR}=.039, \mathrm{CFI}=.975$, and RMSEA $=.034$. Following $\mathrm{Hu}$ and Bentler (1999), this shows that the measurement model achieved an excellent fit.

\section{Table 3}

Discriminant validity

\begin{tabular}{|l|l|l|l|l|l|l|l|l|l|l|l|}
\hline & CR & AVE & MSV & IMI & CRE & ATT & PUR & IMA & SAT & PEE & EXP \\
\hline IMI & 0.918 & 0.692 & 0.301 & $\mathbf{0 . 8 3 2}$ & & & & & & & \\
\hline CRE & 0.898 & 0.688 & 0.301 & $0.549^{* * *}$ & $\mathbf{0 . 8 3 0}$ & & & & & & \\
\hline ATT & 0.830 & 0.619 & 0.255 & $0.505^{* * *}$ & $0.260^{* * *}$ & $\mathbf{0 . 7 8 7}$ & & & & & \\
\hline PUR & 0.790 & 0.557 & 0.088 & $0.273^{* * *}$ & 0.093 & $0.251^{* * *}$ & $\mathbf{0 . 7 4 6}$ & & & & \\
\hline IMA & 0.850 & 0.655 & 0.127 & $0.323^{* * *}$ & $0.158^{*}$ & $0.275^{* * *}$ & $0.297 * * *$ & $\mathbf{0 . 8 0 9}$ & & & \\
\hline SAT & 0.840 & 0.636 & 0.132 & $0.268^{* * *}$ & $0.363^{* * *}$ & 0.054 & 0.009 & -0.102 & $\mathbf{0 . 7 9 8}$ & & \\
\hline PEE & 0.787 & 0.555 & 0.258 & $0.508^{* * *}$ & $0.324 * * *$ & $0.422^{* * *}$ & $0.213^{* *}$ & $0.357^{* * *}$ & $0.153^{*}$ & $\mathbf{0 . 7 4 5}$ & \\
\hline EXP & 0.778 & 0.539 & 0.256 & $0.496^{* * *}$ & $0.244^{* * *}$ & $0.379 * * *$ & $0.134 \dagger$ & $0.263 * * *$ & 0.026 & $0.506 * * *$ & $\mathbf{0 . 7 3 4}$ \\
\hline
\end{tabular}

Note: $* * *$ significant at $\mathrm{p}<.001$. Diagonal figures are the square roots of AVE Source: Author's calculation

\subsection{Structural model assessment}

An analysis of the structural model was subsequently carried out to verify all proposed hypotheses. Table 4 entails the results of the hypothesis testing. All hypotheses are statistically significant at different levels. Model fit measures revealed that $\chi 2=413.729, p=.000$ with 302 df. With the $\chi^{2 / d f}$ value of 1.370 being within the thresholds of 1 and 3 , the model was proved to be parsimonious. The SRMR was .046, RMSEA was .035, while CFI was .973. Overall, all findings revealed that our model renders absolute and incremental goodness of fit from an acceptable to an excellent level (Hair et al., 2019; Hu \& Bentler, 1999). All associations were significant statistically. Table 4 exhibits the findings from the structural model evaluation. 


\section{Table 4}

Hypotheses testing

\begin{tabular}{|l|l|l|l|l|l|}
\hline Hypothesis & Relationship & Estimate & C.R. & P-value & Decision \\
\hline H1 & CRE $\rightarrow$ IMI & 0.243 & 6.66 & $* * *$ & Supported \\
\hline H2 & ATT $\rightarrow$ IMI & 0.271 & 4.74 & $* * *$ & Supported \\
\hline H3 & IMA $\rightarrow$ IMI & 0.131 & 2.37 & 0.018 & Supported \\
\hline H4 & SAT $\rightarrow$ IMI & 0.13 & 2.63 & 0.009 & Supported \\
\hline H5 & PEE $\rightarrow$ IMI & 0.182 & 3.51 & $* * *$ & Supported \\
\hline H6 & EXP $\rightarrow$ IMI & 0.252 & 4.57 & $* * *$ & Supported \\
\hline H7 & IMI $\rightarrow$ PUR & 0.3 & 3.7 & $* * *$ & Supported \\
\hline
\end{tabular}

Note: $* * *$ significant at $\mathrm{p}<.001$

Source: Author's calculation

\section{Discussion}

Our study examines how celebrity characteristics, personal characteristics, and social characteristics impact consumer buying behavior via imitation behavior using the case Toyota Vios brand. Our findings are similar to other studies resulting in consumers' imitation and continue to influence their buying intent (Awasthi \& Choraria, 2015; Choi \& Rifon, 2012; Knoll \& Matthes, 2017). Our study emphasizes that imitation behavior is to plays a significant role in influencing public perceptions about advertising for celebrities, which is in line with Awasthi and Choraria (2015). This demonstrates the attraction, credibility, and product-match image of celebrities affects consumers' attitudes through the mediating role of imitation behavior (Awasthi \& Choraria, 2015; Eisend \& Langner, 2010; Simmers, Damron-Martinez, \& Haytko, 2009). A celebrity who is attractive and credible would have more chances of persuading customers if they imitate her mannerisms (Awasthi \& Choraria, 2015). If the public imitates celebrity image, an attractive and credible celebrity will have better odds of impressing clients. Customer satisfaction often affects behavior through the mediation of emulation (e.g., Awasthi \& Choraria, 2015). This implies an ad that promotes a celebrity's copycat behavior, and its conduct would then be imitated by the community, would be beneficial for consumers who are self-pleased, which is consistent to Anwar and Gulzar (2011). It is also proved that the expression of power is found to directly influence the attitude of celebrity advertising (Nadeau, Balsan, \& Rochlen, 2016). This shows that consumers who want to display control are in favor of celebrity deals and don't automatically imitate celebrity behavior. As the connection between imitation behavior and purchasing intention is the strongest effect, there are many previous studies proving this significant relationship, for example, Inkon (2013).

\subsection{Practical implications}

Following our findings, several practical implications are provided for marketing managers to increase their sales using celebrity endorsements to affect customer purchase intentions. First, the selection of a suitable celebrity for specific consumer segments is critical. If a celebrity is imitated, then it has a better chance of making the advertisement prosper. Therefore, companies, as well as marketing managers, should pick testimonials with high coverage, particularly in the automobile industry, so choose the endorsers who are professionals to provide reviews of car, and they also have credibility as well as trust from the community and appreciated by the customers. Second, celebrity advertisements must be designed in such a manner that they encourage 
consumers to copy them. When individuals mimic celebrity acts, the challenge is to combine the value proposition and the utilization of market offerings into the unique characteristics of the celebrity actions that they emulate. Third, the study has reaffirmed the significance of consumers' attitudes regarding celebrity endorsements and advertisements. Creating a good attitude towards the commercial will increase the likelihood of clients making purchases as a result of the marketing.

\subsection{Limitations and further research}

There are certain drawbacks in our study. First, this study is only done for customers who buy Toyota Vios cars in Vietnam using convenience and snowball sampling methods. If the study is repeated but uses probability sampling, generalization of the findings may be achieved. Second, there are only three characteristics corresponding to six factors, namely: Celebrity characteristics (i.e., credibility, attractiveness, product-image match), personal characteristics (i.e., self satisfaction and expression power), and social characteristics (i.e., peer influence) appearing in the model whereas other factors, for example, culture, can influence results as well. Therefore, future studies should be done using other elements of celebrity endorsement. Third, the quantitative approach does not provide insight into how celebrities inspire customers. Future research may use a qualitative approach to gain a better insight with regard to the thorough perception of celebrities' effect on customer buying intentions.

\section{References}

Alam, S. S., \& Sayuti, N. M. (2011). Applying the Theory of Planned Behavior (TPB) in food purchasing. International Journal of Commerce and Management, 21(1), 8-20. doi:10.1108/10569211111111676

Amos, C., Holmes, G., \& Strutton, D. (2008). Exploring the relationship between celebrity endorser effects and advertising effectiveness. International Journal of Advertising, 27(2), 209-234. doi:10.1080/02650487.2008.11073052

Anderson, J. C., \& Gerbing, D. W. (1988). Structural equation modeling in practice: A review and recommended two-step approach. Psychological Bulletin, 103(3), 411-423. doi:10.1037/0033-2909.103.3.411

Anwar, S., \& Gulzar, A. (2011). Impact of perceived value on word of mouth endorsement and customer satisfaction: Mediating role of repurchase intentions. International Journal of Economics and Management Sciences, 1(5), 46-54.

Apesteguia, J., Huck, S., Oechssler, J., \& Weidenholzer, S. (2010). Imitation and the evolution of Walrasian behavior: Theoretically fragile but behaviorally robust. Journal of Economic Theory, 145(5), 1603-1617. doi:10.1016/j.jet.2010.02.014

Armstrong, G., Adam, S., Denize, S., \& Kotler, P. (2014). Principles of marketing. Harlow, UK: Pearson.

Awasthi, A. K., \& Choraria, S. (2015). Effectiveness of celebrity endorsement advertisements: The role of customer imitation behaviour. Journal of Creative Communications, 10(2), 215234. doi: $10.1177 / 0973258615597412$

Baldry, A. C., \& Farrington, D. P. (2000). Bullies and delinquents: Personal characteristics and parental styles. Journal of Community \& Applied Social Psychology, 10(1), 17-31. doi:10.1002/(SICI)1099-1298(200001/02)10:1<17::AID-CASP526>3.0.CO;2-M 
Bandura, A. (2006). Social learning theory of aggression. Journal of Communication, 28(3), 1229. doi:10.1111/j.1460-2466.1978.tb01621.x

Batra, R., \& Ray, M. L. (1986). Affective responses mediating acceptance of advertising. Journal of Consumer Research, 13(2), 234-249. doi:10.1086/209063

Baumeister, R. F. (1991). Meanings of life: New York, NY: Guilford Press.

Bearden, W. O., Netemeyer, R. G., \& Teel, J. E. (1989). Measurement of consumer susceptibility to interpersonal influence. Journal of Consumer Research, 15(4), 473-481. doi: $10.1086 / 209186$

Belch, G. E., \& Belch, M. A. (2004). Advertising and promotion: An integrated marketing communications perspective (6th ed.). New York, NY: McGraw-Hill.

Bollen, K. A. (1989). Structural equations with latent variables. New York, NY: Wiley.

Borenstein, E., \& Ruppin, E. (2005). The evolutionary link between mirror neurons and imitation: An evolutionary adaptive agents model. Behavioral and Brain Sciences, 28(2), 127-128. doi:10.1017/S0140525X05240037

Choi, S. M., \& Rifon, N. J. (2012). It is a match: The impact of congruence between celebrity image and consumer ideal self on endorsement effectiveness. Psychology \& Marketing, 29(9), 639-650. doi:10.1002/mar.20550

Colton, D., \& Covert, R. W. (2015). Designing and constructing instruments for social research and evaluation. Hoboken, NJ: Wiley.

Cross, R. G., \& Dixit, A. (2005). Customer-centric pricing: The surprising secret for profitability. Business Horizons, 48(6), 483-491. doi:10.1016/j.bushor.2005.04.005

Dima, I. C., Teodorescu, M., \& Gîfu, D. (2014). New communication approaches vs. traditional communication. International Letters of Social and Humanistic Sciences, 31, 46-55. doi:10.18052/www.scipress.com/ILSHS.31.46

Eisend, M., \& Langner, T. (2010). Immediate and delayed advertising effects of celebrity endorsers' attractiveness and expertise. International Journal of Advertising, 29(4), 527546. doi:10.2501/S0265048710201336

Elleström, L. (2018). A medium-centered model of communication. Semiotica, 2018(224), 269293. doi:10.1515/sem-2016-0024

Fornell, C., \& Larcker, D. F. (1981). Evaluating structural equation models with unobservable variables and measurement error. Journal of Marketing Research, 18(1), 39-50. doi:10.1177/002224378101800104

Freire, O., Quevedo-Silva, F., Senise, D., \& Scrivano, P. (2018). The effectiveness of celebrity endorsement in aspiring new celebrities. RAUSP Management Journal, 53(3), 289-303. doi:10.1108/RAUSP-04-2018-011

Friedman, H. H., Termini, S., \& Washington, R. (1976). The effectiveness of advertisements utilizing four types of endorsers. Journal of Advertising, 5(3), 22-24. doi:10.1080/00913367.1976.10672647

Gauns, K. K., Pillai, S. K. B., Kamat, K., Chen, R. F., \& Chang, L.-C. (2018). impact of celebrity endorsement on consumer buying behaviour in the State of Goa. IIM Kozhikode Society \& Management Review, 7(1), 45-58. doi:10.1177/2277975217733897 
Hair, J. F., Black, W. C., Babin, B. J., \& Anderson, R. E. (2019). Multivariate data analysis (8th ed.). Andover, Hampshire: Cengage Learning.

Hani, S., Marwan, A., \& Andre, A. (2018). The effect of celebrity endorsement on consumer behavior: Case of the Lebanese jewelry industry. Arab Economic and Business Journal, 13(2), 190-196. doi:10.1016/j.aebj.2018.11.002

Hoffman, M. W., Grimes, D. B., Shon, A. P., \& Rao, R. P. N. (2006). A probabilistic model of gaze imitation and shared attention. Neural Networks, 19(3), 299-310. doi:10.1016/j.neunet.2006.02.008

Homer, P. M., \& Kahle, L. R. (1988). A structural equation test of the value-attitude-behavior hierarchy. Journal of Personality and Social Psychology, 54(4), 638-646. doi:10.1037/00223514.54.4.638

Hu, L. t., \& Bentler, P. M. (1999). Cutoff criteria for fit indexes in covariance structure analysis: Conventional criteria versus new alternatives. Structural Equation Modeling: A Multidisciplinary Journal, 6(1), 1-55. doi:10.1080/10705519909540118

Inkon, K. (2013). A study on luxuries possession desires and purchase intention: A comparative study between luxuries and imitations. Academy of Entrepreneurship Journal, 19(3), 63-78.

Joshi, Y., \& Rahman, Z. (2015). Factors affecting green purchase behaviour and future research directions. International Strategic Management Review, 3(1), 128-143. doi:10.1016/j.ism.2015.04.001

Kamins, M. A., \& Gupta, K. (1994). Congruence between spokesperson and product type: A matchup hypothesis perspective. Psychology \& Marketing, 11(6), 569-586. doi:10.1002/mar.4220110605

Kim, Y.-J., \& Na, J.-H. (2007). Effects of celebrity athlete endorsement on attitude towards the product: The role of credibility, attractiveness and the concept of congruence. International Journal of Sports Marketing and Sponsorship, 8(4), 23-33. doi:10.1108/IJSMS-08-04-2007B004

Kitayama, S., \& Uskul, A. K. (2011). Culture, mind, and the brain: Current evidence and future directions. Annual Review of Psychology, 62(1), 419-449. doi:10.1146/annurev-psych120709-145357

Knoll, J., \& Matthes, J. (2017). The effectiveness of celebrity endorsements: A meta-analysis. Journal of the Academy of Marketing Science, 45(1), 55-75. doi:10.1007/s11747-016-0503-8

Koustelios, A. D. (2001). Personal characteristics and job satisfaction of Greek teachers. International Journal of Educational Management, 15(7), 354-358. doi:10.1108/EUM0000000005931

Kutthakaphan, R., \& Chokesamritpol, W. (2013). The use of celebrity endorsement with the help of electronic communication channel (instagram): Case study of magnum ice cream in Thailand. Retrieved January 05, 2022, from https://www.divaportal.org/smash/get/diva2:626251/FULLTEXT01.pdf

Lafferty, B. A., \& Goldsmith, R. E. (1999). Corporate credibility's role in consumers' attitudes and purchase intentions when a high versus a low credibility endorser is used in the ad. Journal of Business Research, 44(2), 109-116. doi:10.1016/S0148-2963(98)00002-2 
Lee, J.-G., \& Thorson, E. (2008). The impact of celebrity-product incongruence on the effectiveness of product endorsement. Journal of Advertising Research, 48(3), 433-449. doi: $10.2501 / \mathrm{s} 0021849908080446$

Manz, C. C., \& Sims, H. J. (1980). Self-management as a substitute for leadership: A social learning theory perspective. Academy of Management Review, 5(3), 361-367. doi:10.5465/amr.1980.4288845

McCracken, G. (1989). Who is the celebrity endorser? Cultural foundations of the endorsement process. Journal of Consumer Research, 16(3), 310-321. doi:10.1086/209217

Meltzoff, A. N., \& Moore, M. K. (1994). Imitation, memory, and the representation of persons. Infant Behavior and Development, 17(1), 83-99. doi:10.1016/0163-6383(94)90024-8

Nadeau, M. M., Balsan, M. J., \& Rochlen, A. B. (2016). Men's depression: Endorsed experiences and expressions. Psychology of Men \& Masculinity, 17(4), 328-335. doi:10.1037/men0000027

Nehaniv, C. L., Polani, D., Dautenhahn, K., Beokhorst, R. t., \& Cañamero, L. (2002). Meaningful information, sensor evolution, and the temporal horizon of embodied organisms. Paper presented at the Proceedings of the eighth international conference on Artificial life, MIT Press, Cambridge, Massachusetts, USA.

Nelson, J., \& Aboud, F. E. (1985). The resolution of social conflict between friends. Child Development, 56(4), 1009-1017. doi:10.2307/1130112

Nguyen, P. V. (2017). Celebrity endorsement as the drivers of an advertising strategy: The case of Toc Tien endorsing OPPO. VNU Journal of Science: Economics and Business, 33(2), 87100. doi:10.25073/2588-1108/vnueab.4074

Noë, R., van Schaik, C. P., \& van Hooff, J. A. R. A. M. (1991). The market effect: An explanation for pay-off asymmetries among collaborating animals. Ethology, 87(1/2), 97-118. doi:10.1111/j.1439-0310.1991.tb01192.x

Nunnly, J., \& Bernstein, I. (1994). Psychometric theory (3rd ed.). New York, NY: McGrawHill.

Nye, J. S. (1990). The changing nature of world power. Political Science Quarterly, 105(2), 177192. doi: $10.2307 / 2151022$

Perreault, T. (2014). What kind of governance for what kind of equity? Towards a theorization of justice in water governance. Water International, 39(2), 233-245. doi:10.1080/02508060.2014.886843

Phelps, J. E., \& Hoy, M. G. (1996). The Aad-Ab-PI relationship in children: The impact of brand familiarity and measurement timing. Psychology \& Marketing, 13(1), 77-105. doi:10.1002/(SICI)1520-6793(199601)13:1<77::AID-MAR5>3.0.CO;2-M

Piehler, T. F. (2011). Peer influence. In B. B. Brown \& M. J. Prinstein (Eds.), Encyclopedia of Adolescence (pp. 249-254). San Diego, CA: Academic Press.

Reid, L. N., \& Soley, L. C. (1983). Decorative models and the readership of magazine ads. Journal of Advertising Research, 23(2), 27-32.

Roozen, I., \& Claeys, C. (2010). The relative effectiveness of celebrity endorsement for print advertisement. Review of Business and Economic Literature, LV(1), 76-89.

Rosenstock, I. M., Strecher, V. J., \& Becker, M. H. (1988). Social learning theory and the health belief model. Health Education Quarterly, 15(2), 175-183. doi:10.1177/109019818801500203 
Roth, M. S., \& Romeo, J. B. (1992). Matching product category and country image perceptions: A framework for managing country-of-origin effects. Journal of International Business Studies, 23(3), 477-497. doi:10.1057/palgrave.jibs.8490276

Schimmelpfennig, C. (2018). Who is the celebrity endorser? A content analysis of celebrity endorsements. Journal of International Consumer Marketing, 30(4), 220-234. doi:10.1080/08961530.2018.1446679

Shadish, W. R., Cook, T. D., \& Campbell, D. T. (2002). Experimental and quasi-experimental designs for generalized causal inference. Boston, MA: Houghton, Mifflin and Company.

Simmers, C. S., Damron-Martinez, D., \& Haytko, D. L. (2009). Examining the effectiveness of athlete celebrity endorser characteristics and product brand type: The endorser sexpertise continuum. Journal of Applied Sport Management, 1(1), 52-64. doi:10.7290/jasm

Simon, H. A. (1953). Notes on the observation and measurement of political power. The Journal of Politics, 15(4), 500-516. doi:10.2307/2126538

Smith, J. M., \& Parker, G. A. (1976). The logic of asymmetric contests. Animal Behaviour, 24(1), 159-175. doi:10.1016/S0003-3472(76)80110-8

Stacks, D. W., Salwen, M. B., \& Eichhorn, K. C. (2019). An integrated approach to communication theory and research. New York, NY: Routledge.

Stafford, L. (2004). Communication competencies and sociocultural priorities of middle childhood. In A. L. Vangelisti (Ed.), Handbook of family communication (pp. 311-332). Mahwah, NJ,: Lawrence Erlbaum Associates Publishers.

Thanh Huong (2017). Toyota Việt Nam chọn Nũ hoàng nhạc rap Suboi làm Đại sú thuoong hiệu [Toyota Vietnam chooses Rap Queen Suboi as brand ambassador]. Retrieved January 05, 2021, from https://baodautu.vn/toyota-viet-nam-chon-nu-hoang-nhac-rap-suboi-lam-daisu-thuong-hieu-d69406.html

Theodorakis, Y., Malliou, P., Papaioannou, A., Beneca, A., \& Filactakidou, A. (1996). The effect of personal goals, self-efficacy, and self-satisfaction on injury rehabilitation. Journal of Sport Rehabilitation, 5(3), 214-223. doi:10.1123/jsr.5.3.214

Thuy Lien (2016). Suboi chụp ảnh cho Kenzo x H\&M cùng dàn sao quốc tế [Suboi took photos for Kenzo x H\&M with international stars]. Retrieved January 05, 2021, from https://vnexpress.net/suboi-chup-anh-cho-kenzo-x-h-amp-m-cung-dan-sao-quoc-te3467222.html

Till, B. D., \& Busler, M. (1998). Matching products with endorsers: Attractiveness versus expertise. Journal of Consumer Marketing, 15(6), 576-586. doi:10.1108/07363769810241445

Till, B. D., \& Busler, M. (2000). The match-up hypothesis: Physical attractiveness, expertise, and the role of fit on brand attitude, purchase intent and brand beliefs. Journal of Advertising, 29(3), 1-13. doi:10.1080/00913367.2000.10673613

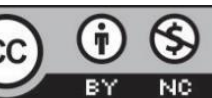

Creative Commons Attribution-NonCommercial 4.0 International License. 